СОЦІАЛЬНЕ ОБСЛУГОВУВАННЯ ЛЮДЕЙ 3 ІНВАЛІДНІСТЮ ЗА КОРДОНОМ: КРАЩИЙ ДОСВІД I МОЖЛИВОСТІ ЙОГО ВПРОВАДЖЕННЯ В УКРАЇНІ

\title{
SOCIAL SERVICES FOR PEOPLE WITH DISABILITIES ABROAD: BETTER EXPERIENCE AND POSSIBILITIES OF ITS IMPLEMENTATION IN UKRAINE
}

Удк 364.4-056.26(100+477)

DOI https://doi.org/10.32843/2663-60852020-20-1-30

\section{Молоченко І.А.,}

аспірант кафедри соціальної педагогіки та соціальної роботи

Уманського державного педагогічного університету імені Павла Тичини

\begin{abstract}
Стаття присвячена проблемі соціального обслуговування людей з інвалідністю на прикладі роботи зарубіжних країн. 3 їх досвіду взято основні аспекти роботи з людьми з інвалідністю. Шляхи подолання проблем та покращення їхнього життя у різних його сфрерах. У побутових щоденних справах, під час працевлаштування та безпосередньо під час робочого прочесу, у період психологічної та фрізичної реабілітації, також відновлення їхніх життєвих сил. Також розелянуто роботу у напрямку соціальної срери таких країн як: Сполучені Штати Америки, Канада, Японія та різних країн Європи: Франції, Великої Британії, Німеччини, Польщі, Литви, Болгарії, Угорщини, Італії, Швеції, Нідерландів. Розкрито діяльність зарубіжних країн у сфрері соціального страхування, соціального захисту й у наданні соціальних послуг людям з інвалідністю і не тільки, що грунтується на їхньому законодавстві. Проаналізовано дослідження різних вчених, у яких сфоормовані відмінності яких бракує нашій країні в порівнянні із зарубіжними. На основі результатів цих досліджень визначено можливості впровадження різних форм соціального обслуговування за кордоном в діяльність соціальної ссрери України.
\end{abstract}

Ключові слова: люди з інвалідністю, соціальне обслуговування, соціальна політика, реабілітація, зарубіжний досвід.

The article deals with the problem of social services for people with disabilities, as exemplified by the work of foreign countries. From their experience the main aspects of working with people with disabilities are taken. Ways to overcome problems and improve their lives in various areas. In everyday daily affairs, during employment and directly during the work process, during the period of psychological and physical rehabilitation, also in the restoration of their vital forces. Work in the social sphere of countries such as: United States of America, Canada, Japan and various countries of Europe: France, Great Britain, Germany, Poland, Lithuania, Bulgaria, Hungary, Italy, Sweden, the Netherlands are also considered. The activity of foreign countries in the field of social insurance, social protection and providing social services to people with disabilities is disclosed, and based on their legislation. The research of different scientists in which differences our country with foreign ones is analyzed. Based on the results of these studies, the possibility of introducing different forms of social senvices abroad into the social sphere of Ukraine was determined. Key words: people with disabilities, social services, social policy, rehabilitation, foreign experience.
Постановка проблеми у загальному вигляді. Проблема соціального обслуговування людей 3 інвалідністю $€$ однією 3 актуальніших проблем натепер. Інвалідність сьогодні можна назвати проблемою не однієї людини або групи людей, а всього суспільства загалом. Розвинуті зарубіжні країни навчились вирішувати цю проблему та мають перевірену роками і вдало запроваджену систему соціального захисту своїх громадян. Аналіз якої дасть змогу запропонувати корективи та шляхи реалізації змін у вітчизняній системі соціального обслуговування людей з інвалідністю.

Аналіз останніх досліджень і публікацій. Вивченням зарубіжного досвіду соціального обслуговування людей 3 інвалідністю займались провідні українські вчені Л. Березовська, Н. Бєлоусова, Н. Глазко, К. Дубич, В. Мельник, Т. Перегудова, Г. Попович, О. Рассказова, Т. Семигіна, О. Сергієнко, П. Таланчук, О. Чернишенко, А. Шевцов.

Виділення не вирішених раніше частин загальної проблеми. Невирішеним залишається узагальнення соціальної роботи за кордоном саме 3 людьми 3 інвалідністю, їх реабілітації та визначення можливостей впровадження такої роботи в Україні.

Мета статті - вивчити досвід зарубіжних країн у ссрері соціального обслуговування людей з інвалідністю й узагальнити рекомендації для удоско- налення вітчизняної системи надання соціальних послуг для соціально вразливихверств населення.

Виклад основного матеріалу. 3 плином культурно-історичного часу удосконалювалися прийоми і форми соціальної роботи, але головне ії завдання залишалося незмінним - формувати у тих, кому потрібна допомога, уміння і навички самовиживання і здатності самому допомогти собі, тобто максимально підвищити ступінь самостійності клієнта, розвинути його здатність контролювати своє життя і самому розв'язувати власні щоденні проблеми.

Система соціального захисту населення в США, охоплює різні соціальні програми, які регламентуються як федеральним законодавством, так і законодавством штатів, що дає змогу достатньо повно й оперативно враховувати потреби у соціальній допомозі окремих регіонів, етнічних та соціальних груп населення.

Важлива складова частина американської державної системи соціального захисту - допомога бідним, що не вимагає попередніх спеціальних внесків. Визначальним критерієм її надання є нужденність чи злидні, а метою - забезпечення гарантованого доходу, підтримка бідних сімей з дітьми, й також продовольча, житлова, медична різновиди допомоги. Програмою забезпечення гарантованого достатку охоплені престарілі, інваліди, сліпі, 
котрим фредеральний уряд виплачує субсидії, що становлять $60 \%$ доходу від офріційно прийнятої «межі бідності».

Соціальна робота з дорослими інвалідами має свої особливості у різних країнах. Зокрема у США вони першочергово забезпечуються пенсіями та страхуванням від нещасних випадків, медичним обслуговуванням. Соціальна підтримка інвалідів за плату від муніципалітетів здійснюється спеціалізованими організаціями й фондами, котрі забезпечують житлово-побутове облаштування, транспортні потреби, навчання й реабілітацію людини, котра раптово втратила здоров'я. Адаптаційна підготовка допомагає інваліду пристосуватися до нових умов, освоїти різні технічні засоби, зміцнити психологічну самостійність та прагнення знайти застосування своїм здібностям. [1]

Ефрективною $є$ практика соціального обслуговування інвалідів та людей з фізичними вадами у Великій Британії. Цією роботою тут зайнято широке коло кваліфікованих працівників, зорганізованих місцевою владою для допомоги інвалідам за місцем проживання, у денних центрах, у пансіонатах і гуртожитках, у лікарнях чи в інтернатах. У Великій Британії важливу роль у регулюванні питань соціального обслуговування громадян відіграють відповідні принципи. Так, до принципів надання соціальних послуг віднесено такі: повна автономність і децентралізація суб'єктів надання соціальних послуг, соціальна інтеграція, розробка соціальних послуг на місцях для задоволення конкретних потреб, відповідальність органів місцевого самоврядування за якість наданих послуг [2].

Велика увага у Великій Британії приділяється питанням догляду вдома. Уперше ці питання були врегульовані в 1995 р. в Законі про догляд. У Стратегії виховання від 1999 р. було закріплено засади виховання та догляду за громадянами, у тому числі й вдома. Вказаними законами визначено особливості соціального обслуговування на дому. Таким чином, у Великобританії надзвичайно пильна увага приділяється питанням соціального захисту, у тому числі й обслуговування дітей-інвалідів. При цьому значну роль відіграють державні органи, що хоч і не відповідає тенденції більшості країн щодо посилення ролі громадських організацій у соціальному обслуговуванні громадян, однак забезпечує досить високу якість соціальних послуг, контроль за такою якістю, а головне - їх належне та своєчасне фрінансування. [2].

3 дослідження Н. Глазко стало відомо «структура фрінансування системи соціального захисту Великобританії визначається поділом цієї системи на дві частини: національну охорону здоров'я та національне соціальне страхування. Перша фрінансується на 90\% із державного бюджету, а друга - за рахунок страхових внесків найманих працівників і підприємців» [11].
Оригінальний досвід комплексної реабілітації інвалідів у рамках кооперації нагромаджено у Польщі. Кооперативи інвалідів 3 допомогою соціальних служб займаються підбором можливих професій та організацією відповідного навчання, забезпеченням умов праці, адекватних здоров'ю інвалідів, пристосуванням робочих місць до наявного в людини дефекту тощо. Об'єднання й кооперування інвалідів створює кращі умови не лише для медичної, а й соціальної реабілітації. ще одна важлива соціальна проблема за кордоном - робота з дітьми-інвалідами, їх медико-соціальна адаптація і життєва самореалізація. Діти 3 окремими фрізичними вадами спроможні навчатися і за програмою для звичайних дітей. Проте можливостей школи не завжди достатньо для бажаної реабілітації. Тому в Болгарії, Угорщині, на Кубі організовано денні реабілітаційні стаціонари, в яких створені умови для проведення комплексу відновлювальних заходів та відпочинку дітей. [3]

О. Березін, М. Безпарточний і Л. Нікілєва визначили особливості фрранцузької системи соціального захисту населення, до яких віднесли розгалужену систему профресійно-галузевих схем соціального страхування, розвинену систему родинних виплат, яка стала результатом тривалої еволюції, значну роль додаткових систем соціального захисту, особливо у ссрері пенсійного й медичного страхування [4].

У Франції соціальні послуги надаються за такими напрямами: ссрера охорони здоров'я, освіта, правосуддя, молодь і спорт, містобудування й муніципалітети, сільськогосподарські кооперативи, а також трудова й профресійна підготовка [5].

Варто зазначити, що у Франції врегулювано питання співвідношення ролі держави й недержавних інституцій у наданні соціальних послуг та контрою за їх якістю [6]. Тож принцип децентралізації $\epsilon$ одним із головних у сорері соціального обслуговування у Франції, також одним із головних суб'єктів надання соціальних послуг є саме громадські організації.

У Федеральному законі Німеччини про соціальне страхування від 23 березня 1994 р. міститься перелік соціальних послуг, які надаються в цій країні [7].

Враховуючи положення законодавчих актів, можна визначити такі види соціальних послуг у Німеччині: послуги із соціального страхування, послуги з надання соціальних допомог, послуги із соціальної підтримки окремих верств населення, зокрема сімей із дітьми, жертв війни, інвалідів та інших категорій громадян [8].

У Німеччині до надання соціальних послуг часто залучаються волонтерські організації, які не мають офріційного статусу [9].

Усі соціальні послуги є добровільними та передбачають активну співпрацю адресатів. Необхід- 
ність цієї співпраці зумовлена тим, що головною метою даних послуг $є$ надання можливості самостійно знаходити правильні рішення й без сторонньої допомоги влаштовувати власне життя. Кожен вид допомоги має свій окремий фраховий профріль і спрямований, на конкретну сімейну чи індивідуальну проблемну ситуацію. Ці послуги є взаємодоповнюючими та взаємопов'язаними, між ними не існує ієрархічних відносин [10].

Діюче законодавство Італії гарантує окремим категоріям громадян та їх сім'ям забезпечення комплексної системи заходів соціального захисту й соціальних послуг, передбачає проведення універсальної політики щодо підтримки осіб у складному становищі шляхом надання ефективних і високоякісних послуг, які сприяють покращенню якості життя, забезпеченню рівних можливостей, недопущенню дискримінації й звуження громадянських прав, попередженню, усуненню та зведенню до мінімуму соціального відчуження [12].

За результатами вивчення європейських практик протидії соціальному виключенню громадян Т. Перегудова доводить «доволі широку палітру механізмів, які вбудовані в систему соціального захисту населення, що може бути позитивним прикладом для України». Насамперед це передбачення «пастки бідності». [20]

У Литві в систему соціального забезпечення входить піклування про розвиток ринку праці та створення робочих місць. А саме соціальна політика направлена на покращення якості життя населення за допомогою розподілу матеріальних засобів у вигляді надання соціальних послуг, які і допомагають людям у складних життєвих обставинах. У Литві соціальна політика складається з трьох основних частин: соціальне страхування, ринок праці та соціальна допомога. У реалізації соціальної політики Литва керується рядом принципів: соціальної справедливості, соціальної відповідальності, солідарності, соціальних гарантій [13].

Особливостями соціальної сфери в Японії $\epsilon$ те, що соціальна підтримка здійснюється у фрормі прямої допомоги 3 громадських орондів фрінансових ресурсів. У державному бюджеті Японії передбачено п'ять напрямів соціальної підтримки: захист життя, соціальне забезпечення, соціальне страхування, підтримку здоров'я та гігієни, допомоги по безробіттю [14].

Дослідження О. Дєгтяр показало нам, що «великий інтерес представляють негативні наслідки існування розвинених систем соціального забезпечення. Зокрема, одним з них $є$ розвиток утриманства та елементів спекуляції» [15].

У Нідерландах практично будь-яка людина, що має проблеми зі здоров'ям, пройшовши разове обстеження, зможе отримати «інвалідність по хворобі» та довічну допомогу в розмірі 70\% заробітної плати на останньому місці роботи. Як наслідок в країні з чисельністю зайнятих 6,2 млн осіб налічується близько 800 тис. громадян, що отримали таку інвалідність [16].

у Швеції, де один 3 найбільш високих стандартів здоров'я населення, має місце найвищий у світі відсоток невиходів на роботу з причини хвороби. Значною мірою це пов'язано з високим рівнем соціальних виплат по хворобі та страхування за короткостроковими захворюваннями [17].

У цьому плані показовий досвід Канади, де система медичного страхування заснована на відрахуваннях роботодавців на ощадні рахунки, і всі кошти, що знаходяться на цих рахунках, євласністю працівника, при їх недостатності працівники оплачують медичні послуги за свій рахунок, а при надлишку коштів залишки на рахунку, що залишилися після завершення розрахункового періоду, також знаходяться у власності робітника. Не виникає питання про нецільове використання коштів [18].

Установлено, що в Угорщині, Польщі, Румунії та Болгарії децентралізація надання соціальних послуг здійснювалася в контексті взятих ними зобов'язань щодо виконання вимог, пов'язаних зі вступом до ЄС, що передбачало проведення системних реформ, впровадження відповідних норм і стандартів у цій сорері. Тому можна вважати що Українавже нашляху допозитивних змін уцій сорері.

У своєму дослідженні Т. Перегудова говорить: «Позитивна практика європейських країн має стати підґрунтям соціальних реформ в Україні. Побудова системи якісних соціальних стандартів людського розвитку передбачає переосмислення основних напрямів соціальної політики, виходячи за межі соціального захисту населення, спираючись на стійке залучення відторгнутого населення до суспільнокорисної діяльності на засадах соціальної інклюзії шляхом створення робочих місць та стимулювання до повернення до трудової діяльності» [19].

Висновки. Отже, розглянувши особливості соціального обслуговування в зарубіжних країнах, можна зробити висновок, що соціальне обслуговування за кордоном на високому рівні, хоч і відрізняється у деяких країнах. Все це базується на достатньому фрінансуванні соціальних потреб певних категорій населення. Також на рівності та доступності всіх і всього. Зарубіжні країни неодноразово переживали зміни та завдяки цьому знайшли найраціональніші шляхи розвитку цієї сорери. Керуючись зарубіжним досвідом, беручи до уваги найяскравіше 3 кожної системи соціального обслуговування адаптуючи це для своїх громадян. Створення бази надання соціальних послуг, відповідно замовленням і реальним потребам населення, що дозволить якісніше та точніше надавати допомогу тільки тим хто цього потребує, з можливою економією бюджету. Покладання обов'язків соціального піклування на громадські організації, залучення їх до надання соціальних послуг. Між- 
секторальний розподіл соціальних послуг серед надавачів і налагодження системи фрінансування. Створення інститутів контролю та перевірки процесу якісно соціального обслуговування громадян та відповідності отримувано допомоги їхнім потребам. Сприяння зайнятості та залучення до різних видів діяльності людей з інвалідністю. Створення та впровадження людиноцентричного підходу в системі соціального захисту для відновлення у людей $з$ інвалідністю відчуття повної захищеності та довіри до власної держави та суспільства. Соціальна політика України може стати потужною сорерою підтримки, конкуруючою з країнами ЄС.

\section{БІБЛІОГРАФІЧНИЙ СПИСОК:}

1. История США : в 4 т. / ред. кол. Г.Н. Севастьянов, Г.А. Арбатов. Москва : Высшая школа, 1986. Т. 3.

2. Положительный опыт предоставления социальных услуг в странах Юго-Восточной Европы. Субрегиональное бюро MOT в Москве. URL: https://www.ilo.org/wcmsp5/groups/public/---europe/ ---ro-geneva/---sro-moscow/documents/publication/ wcms_344712.pdf.

3. Попович Г. Соціальна робота в Україні і за рубежем. Ужгород, 2000.

4. Березін О.В., Безпарточний М.Г., Нікілєва Л.О. Механізми формування та методологія розвитку закладів і підприємств соціального обслуговування. Полтава : ІнтерГрафріка, 2013. 210 с.

5. Анселен Ж. Франция: социальные услуги. Соціальна робота в Україні: теорія і практика. 2013. № 1-2. C. 204-219.

6. Portail de gouvernment. URL: http://www.gouvernement.fr.

7. Bundessozialhilfegesetz in der Fassung der Bekanntmachung vom 23. Marz 1994 (BGBI. I S. 646, 2975), zuletzt geandert durch Art. 4 des Gesetzes zur Familienforderung vom 22. Dezember 1999 (BGBI. I S. 2552). URL: http://www.gesetzesweb.de/ BSHG.html.
8. Германия. Вызовы XXI века / отв. ред.: В.Б. Белов. Весь мир. 2009.

9. Боде И. Германия: социальные услуги. Соціальна робота в Україні: теорія і практика. 2013. № 1-2. C. 220-226.

10. Seithe, M. Hilfen zur Erziehung. Handbuch Familie / Ecarius, J. Weinheim: VS Verlag fur Sozialwissenschaften, 2007. S. 568-592.

11. Глазко Н.Д. Зарубіжний досвід забезпечення соціальної сфери. Ефрективна економіка. 2014. Вип. 5.

12. Хомченко O.Е. Реализация комплексной системы мер социальной защиты и социальных услуг в Италии. Вестник РУДН. Серия «Юридические науки». 2013. № 1. С. 91-100.

13. Чюжас Р.А., Вайцекаускене В.Й. Основы создания социальных услуг в социальной политике Литвы. Соціальна робота в Україна: теорія і практика. Розділ. Міжнародний досвіт. 2010. Вип. 4 (31). С. 1-5.

14. Сергієнко О. Соціальна політика в сучасному світі та в Україні. Україна: аспекти праці. 2013. № 1. С. 31-37.

15.Дєгтяр О. Рівень ресурсного забезпечення соціальної ссери в економічно розвинених країнах світу. Держава і ринок.

16. Білинська М.М. Державне управління галузевими стандартами в умовах реформування вищої медичної освіти в Україні : монографія / Нац. акад. держ. упр. при Президентові України. Київ : НАДУ, 2004. 246 c.

17.Гришин И. Социал-демократия Швеции: трудное расставание с прошлым. Мировая экономика и международные отношения. 2011. № 9. С. 72-84.

18. Черниш О.І. Ринок послуг: механізми державного регулювання в трансформаційній економіці : монографрія / під заг. ред. В.В. Дорофрієнка. Донецьк : РВК ПРОМО, 2005. 410 c.

19. Перегудова Т.В. Соціальна інклюзія як елемент соціальної політики: європейські уроки для України. Науковий вісник Міжнародного гуманітарного університету. 